\title{
Foreword
}

\section{International Symposium on Propionibacteria and Bifidobacteria: dairy and probiotic applications}

This special issue contains most of the oral presentations made at the 2004 International Symposium on Propionibacteria and Bifidobacteria held at the Palais du Grand Large in Saint-Malo.

Since the creation of the first symposium on dairy propionibacteria in Rennes (May 1995), two others have been organised, successively, in Cork in 1998 and in Zurich in 2001. All three provided a great and friendly opportunity of scientific exchanges. However, if the use of dairy propionibacteria as starters in Swiss cheese remains their main industrial application, the literature regarding their potential health benefits has increased drastically since 2001: "Propionic as probiotics, dream or reality?!" This new field requires the extension of scientific exchanges and challenges, and we decided to widen the scope of the symposium.

Bifidobacteria have been studied for many years all over the world because of their claimed health benefits. As propionibacteria and bifidobacteria are both Gram-positive GC-rich Actinobacteria (much closer together than they are to lactic acid bacteria), sharing many similar research questions, we took on the challenge of bringing both genera together in the same symposium.

The scientific programme was constructed to answer in two days various questions, in particular: what do we know about their genomics? About their transformation ability? What are the current tools to identify them precisely and to follow their growth or survival in various products? Quantitatively and qualitatively at the strain level? What do we know about their ability to produce bacteriocins, polysaccharides, vitamins, CLA, etc.? Last but not least, what is proven in vivo about their health benefits? What is known about the mechanisms involved?

Our sincere hope was to generate by this symposium fruitful interactions between "propio" and "bifido" aficionados, since we are convinced that we really have a lot to exchange.

With our best regards

Sylvie Lortal

$\mathrm{P} / \mathrm{o}$ the organising committee

UMR Science et Technologie du Lait et de l'Ouf

INRA-Agrocampus Rennes

France 


\section{Sponsoring and Partnership}

\section{Partnership:}

Institut National de la Recherche Agronomique (www.inra.fr)

\section{Financial support:}

Applied Biosystems (www.appliedbiosystems.com)

Bongrain SA (www.bongrain.com)

Chr Hansen (www.chr-hansen.com)

DSM Food Specialties (www.dsm.com/en_US/html/dfs/home.htm)

Lactalis (www.lactalis.fr)

Laiterie de Saint-Malo

Nestlé (www.nestle.com)

Région Bretagne (www.region-bretagne.fr/CRB)

Société Française de Microbiologie (www.sfm.asso.fr)

Standa Industrie (www.standa-fr.com)

\section{Material support:}

Amersham Biosciences (www.amershambiosciences.com)

Centre Interprofessionnel de la Documentation Laitière (www.cidil.fr)

Comité Régional du Tourisme de Bretagne (www.tourismebretagne.com)

EDP Sciences (www.edpsciences.org)

Institut Technique Français des Fromages (www.alimentec.com/accueil/itff)

Office de Tourisme de Saint-Malo (www.saint-malo-tourisme.com)

Président (www.president.fr) 